\title{
Impact of Public Goods on Economic Growth Gaps among Regions of China - from the Perspective of Public Finance
}

\author{
Maoguo Wu \\ Tanyue Sun \\ $\mathrm{Yu}$ Zhou
}

SHU-UTS SILC Business School, Shanghai University, China

doi: 10.19044/esj.2016.v12n25p373 URL:http://dx.doi.org/10.19044/esj.2016.v12n25p373

\begin{abstract}
Based on the economic growth model of public expenditures, this paper assesses the contribution of public expenditures to economic growth among the East, Centre and West of China from 2007 to 2014. This paper attempts to explain the differences of the output per capita in these three regions from the perspective of disparities of investment in public goods determined by public finance and finds that public expenditures have effects on regional differences so that proper types of fiscal expenditures should be invested based on the regional economic characteristics.
\end{abstract}

Keywords: Higher education, intellectual leadership, piloting, scientist, role

\section{Introduction}

Since the start of reform and opening up in 1978, Chinese economy has achieved spectacular success. The East was given the priority to first develop ahead of other regions thanks to the good economic foundation and national preferential policies initiated in 1992. Although this rapid development has also boosted the economic growth within the whole country, economic gaps in the East, Centre and West have become wider. In 2015, gross domestic product (GDP) per capita of 2014 issued by the International Monetary Fund (IMF) indicates that the GDP per capita of first-tier cities whose development grew most quickly in China already exceeded 15,000 dollars, which matched the GDP per capita of developed countries, while the GDP per capita of some cities in the West was less than 1,400 dollars. Compared to the rapid economic development of Eastern region, the economic backwardness of Western region has become a major hidden trouble which has an adverse effect on the stable and sustainable development in this area. 
What leads to the enormous disparities between the East and the West? Ragnar Nurkse, a development economist, argued in the theory of vicious circle of poverty that: "low income would result in low capability of savings. Lack of savings would cause the shortage of capital formation which would hamper the improvement of productivity. As a result, low income remerges due to low productivity. In other words, a region is poor because of its poor." As for the Western region which suffered from the vicious circle of poverty, could the government regard increase in public finance as a powerful driver to facilitate its development? Which types of public financial expenditures could promote the economic growth in the West effectively if public financial expenditures play an essential role in accelerating development? This paper illustrates theoretically that public financial expenditures could boost the economic development via an increase in regional public goods and investigates the influences of 12 different public financial expenditures on the economic growth in the East, Centre, and West utilizing data from National Bureau of Statistics of China (NSBC).

The remaining part of this paper is organized as follows. Section 2 reviews related literature. Section 3 is devoted to descriptive statistical analysis. Section 4 presents empirical tests. Section 5 concludes the paper and provides policy implications.

\section{Related Literature}

\subsection{Causes of Economic Development Disparities}

There are various reasons related to the differences of economic growth. This paper mainly focuses on three aspects:

1. Economic growth theory. According to the conventional economic growth theory, essential factors such as capital, labor, technology and institution promote regional economic growth. Eastern region has comparative advantage in various productive factors both in quantity and quality compared to the Centre and the West.

2. History and location. During Chinese history, the development of the Eastern region and the Central region outperformed that of the Western region in many historical periods. With the rise of modern industry and the increase in international transactions, economy in the East has developed rapidly due to its geographical advantages.

3. National institutional arrangement and strategic choices. Since China was founded in 1949, Chinese government has increased fiscal support and provided more preferential tax policies to the Eastern region. As for the East, it has reasonable industrial structure with high proportions of light industry and tertiary industry. By contrast, the Western region has low proportion of tertiary industry and heavy industry plays a leading role in the industry. 
In light of the three aspects above, the analysis based on the economic growth theory is the main explanation for the economic development disparities among the East, the Centre, and the West. What causes the huge differences of various factors within these regions? Causes must be differences in infrastructure, education, medical level, invention and application of technology etc.. Most of these factors which affect economic development are classified as public goods. Public goods are those products which possess the features of both non-excludable and non-rival so that market mechanism is difficult to supply them sufficiently. Due to this reason, public goods are usually supplied by government via fiscal expenditures. Therefore, fiscal expenditures provided by government have significant influence on the EastWest disparity of economic growth.

\subsection{Differences in Economic Growth Caused by Different Investments in Various Public Goods}

A large number of papers pertain to the effects of investment of public goods on economic development. As indicated above, because of the low efficiency of public goods provided by the market, many public goods are provided by the government. Therefore, the concern of many studies transformed the impacts of public goods on economic growth to the effects of public financial expenditures on economic development.

\subsubsection{Theories of Influences of Public Goods on Economic Growth}

Research on the influences of public goods on economic growth can be divided into two stages. The first stage focuses on exploring the theoretical mechanism of the effects of public goods on economic growth. General growth theory argues that capital is one of the essential factors affecting economic growth. Fiscal expenditures influence economic growth via public investment and further resulted in economic development disparities. At an early stage it is considered that the productive and consumptive public expenditures have different effects on economic growth.

Barro (1990) establishes the first endogenous model of influences of public spending on economic development. In the model, the productive labors of government are introduced into total factor productivity function as another input factor and could act as a substitute of private investment. Barro, Sala-i-Martin (1992) adds mixed public goods with congestion into original model and argues that this type of public goods play a significant role in economic development.

Other research also investigates influences of public goods on economic development based on the new economic growth theory. More new growth factors are added into the economic growth theory. Compared to classical economic theory, extension of this theory considers labor, technology and land 
as essential aspects influencing economic growth. Lucas (1988) introduces public financial expenditures on education to the model of endogenous economic growth and concludes that public spending on education not only increases the stock of human capital, but also accelerates economic development through encouragement of private investments. Devarajan, Swaroop and Zou (1996) includes public goods of education, transportation, national defense into "AK" model and illustrates that the relation between different productive and consumptive public goods and economic growth should be based on the weights of these spending. The relation between nonrecurring public expenditures and economic development is not significant, while current public expenditures promotes economic growth. Similarly, Knoop (1999) demonstrates that when taxes are not cut, the increase in consumptive expenditures of government would depress economic activity based on the model of endogenous economic growth.

\subsubsection{Empirical Tests of Influences of Public Goods on Economic Growth}

It is generally believed that the functions of productive public spending and consumptive public spending on economic development are different. Productive public expenditures plays a main role in economic development, whereas the influence of consumptive public expenditures is ambiguous. In terms of productive expenditures, Arrow, Kurz (1970) treats private capital, productive public spending and technology as explanatory variables and shows that increase in productive public spending would encourage economic development through the increase in capital stock. Introducing time-series data into the Cobb Douglass model, Aschauer (1989) justifies that there exists a positive relation between productive public goods and private investments. Public investment in infrastructure from government plays a vital role in national economic development. From the perspective of developing and developed countries, Butkiewicz and Yanikkaya (2011) points that consumptive public spending would hinder the development of economy in developing countries where the efficiency of government is low. Using data of EU European Union from 1996 to 2012, Boldeanu (2015) finds that unproductive fiscal spending is harmful to GDP per capita. However, according to the data and policies of Hungary and Ireland, Adrienn (2010) indicates that the influences of unproductive expenditures and the policies of non-distortion taxation on economic development are neutral in the long run.

Liu (2009) indicates that increase in social public goods such as education, sanitation and health care could improve people's living condition, increase future expectations, encourage consumption and further stimulate economic development because the nature of public spending has transformed from economic construction to services provision. Ju (2009) points that public 
goods possess positive externality which could promote economic aggregation. Different regional supply of public goods affected the decisions of producers. As a result, capital would flow to regions with high supply level of public goods and realize capital accumulation, promoting economic development. Li and Liu (2012) indicates that the supply of public goods and services not only could be a direct investment to raise the economic benefit, but also it could indirectly affect business productivity and economic development via private investment, capital and labor force. Based on the panel data of 30 provincial level administrative divisions excluding Tibet over the period of 1995 - 2010, Tang and Zhao (2014) shows that increase in public spending stimulates the increase in supply of different factors and has an obvious positive effect on economic development.

\section{Descriptive Statistical Analysis}

\subsection{Economic Development Disparities among the East, Centre and West}

Figure 1 and Table 1 reflect absolute and relative gaps of economic development among the eastern, central and western regions from 2007 to 2014, respectively. In Table 1, the ratios of GDP of different regions represent relative development gaps. According to Table 1, although relative gaps keep narrowing, the differences in the degree of production among these three regions have become wider because of the big magnitude of different regional GDP.

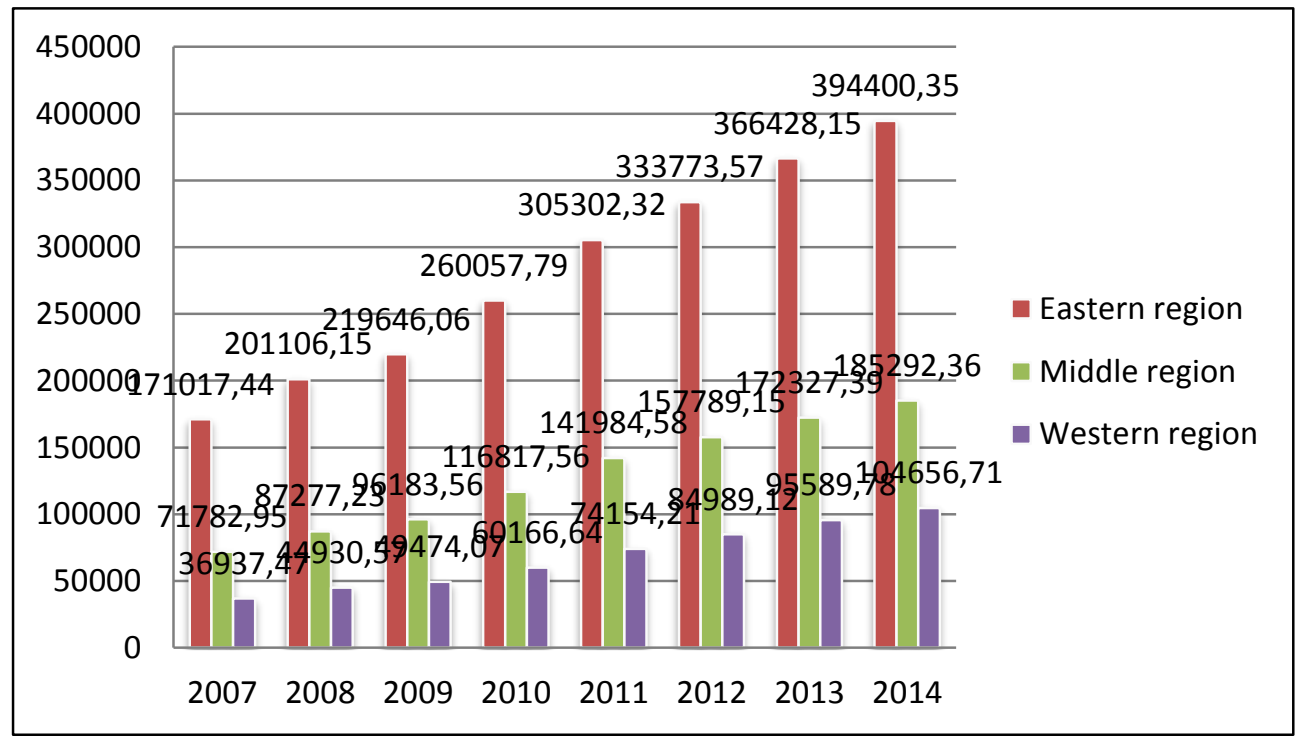

Figure 1 GDP (Hundred Million RMB)

(Sources: China National Bureau of Statistics: http://www.stats.gov.cn) 
Table 1 Ratio of Regional GDP

\begin{tabular}{lccc}
\hline Year & Ratio (East/West) & Ratio (East/West) & Ratio (East/West) \\
\hline 2007 & 4.63 & 2.38 & 1.94 \\
2008 & 4.48 & 2.30 & 1.94 \\
2009 & 4.44 & 2.28 & 1.94 \\
2010 & 4.32 & 2.23 & 1.94 \\
2011 & 4.12 & 2.15 & 1.91 \\
2012 & 3.93 & 2.12 & 1.86 \\
2013 & 3.83 & 2.13 & 1.8 \\
2014 & 3.77 & 2.13 & 1.77 \\
\hline
\end{tabular}

(Source: China National Bureau of Statistics: http://www.stats.gov.cn $)^{1}$

Figure 2 and Table 2 show development differences of the economy in terms of GDP per capita. Since the population of the East is larger than that of the Center and the West, differences of regional GDP per capita are less than that of GDP. When the influences of population are ruled out, the gap between the East and the West narrows noticeably. However, although the relative gap between the East and the West is shrinking, the absolute gap is widening.

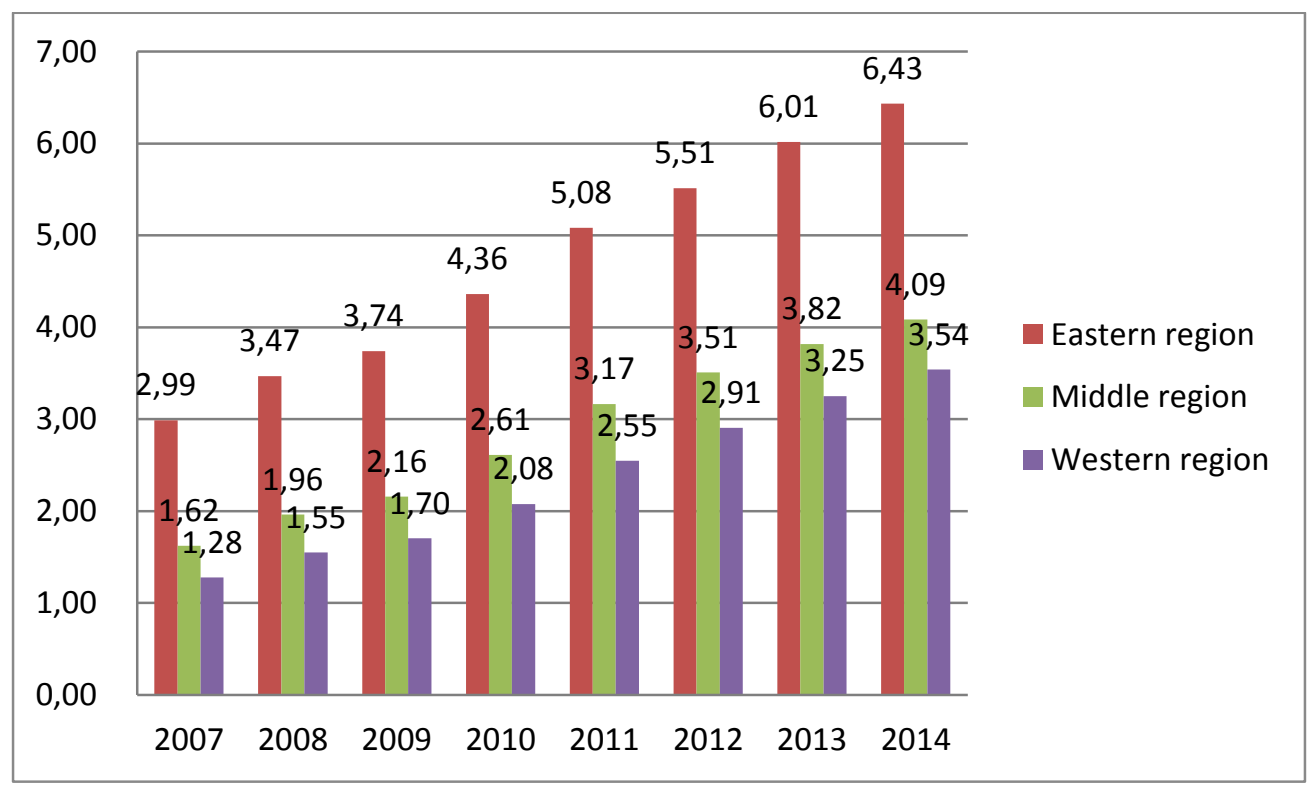

Figure 2 GDP Per Capita (Ten Thousand RMB)

(Data source: China National Bureau of Statistics, http://www.stats.gov.cn)

${ }^{1}$ Note: Numbers in Table 1 are precise to two decimal. 
Table 2 Ratio of Regional GDP Per Capita

\begin{tabular}{lccc}
\hline Year & Ratio (East/West) & Ratio (East/West) & Ratio (East/West) \\
\hline 2007 & 2.34 & 1.84 & 1.27 \\
2008 & 2.24 & 1.77 & 1.27 \\
2009 & 2.20 & 1.73 & 1.27 \\
2010 & 2.10 & 1.67 & 1.26 \\
2011 & 1.99 & 1.61 & 1.24 \\
2012 & 1.90 & 1.57 & 1.21 \\
2013 & 1.85 & 1.58 & 1.17 \\
2014 & 1.82 & 1.57 & 1.15 \\
\hline
\end{tabular}

(Sources: China National Bureau of Statistics: http://www.stats.gov.cn/) ${ }^{2}$

In conclusion, there exist remarkable gaps among the East, the Centre, and the West in terms of both GDP and GDP per capita. The order of regional GDP from the highest to the lowest is: the East, the Centre and the West. GDP of the East is significantly higher than that of other regions. Although the relative gaps of these three regions are reducing, the absolute gaps are increasing. Therefore, there is no sign showing that relatively backward regions have kept up with more developed regions.

\subsection{Differences of Public Financial Expenditures among the East, Centre and West}

Figure 3 illustrates that national fiscal spending increased steadily within the period of 2007-2014. In 2007, the national fiscal spending was 5,000 billion RMB. This spending tripled and reached 15,000 billion RMB in 2014. Such rapid rising tendency shows that public financial expenditures play an increasing role in the economic development with the increasing scale of fiscal spending, which has a significant position in the economy.

\footnotetext{
${ }^{2}$ Note: Numbers in Table 2 are precise to two decimal.
} 


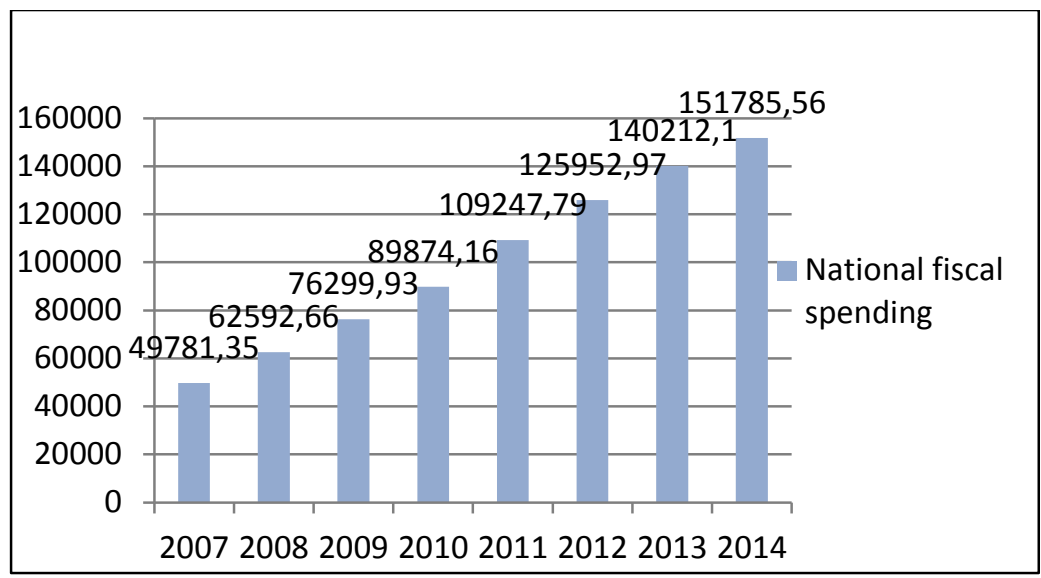

Figure 3 National Fiscal Spending (Hundred Million RMB)

(Sources: China National Bureau of Statistics: http://www.stats.gov.cn)

The relative ratios of fiscal spending are shown in Figure 4. In the period of 2007-2014, the ratio of fiscal spending in the Eastern region to total fiscal spending was the highest. It clearly indicates that fiscal policies have inclined to the East. However, the ratio of the East reduced from 50.4\% to $46.76 \%$ during 2007-1014. In other words, the government was reducing the preferential policies for the East in this period. In contrast, the ratio of fiscal spending in the Central region to total fiscal spending kept stable at a range of 29\%-30\%, while the ratio of the West was the lowest despite an increase in annual investment. This trend means that government is increasing financial support to the Western region.

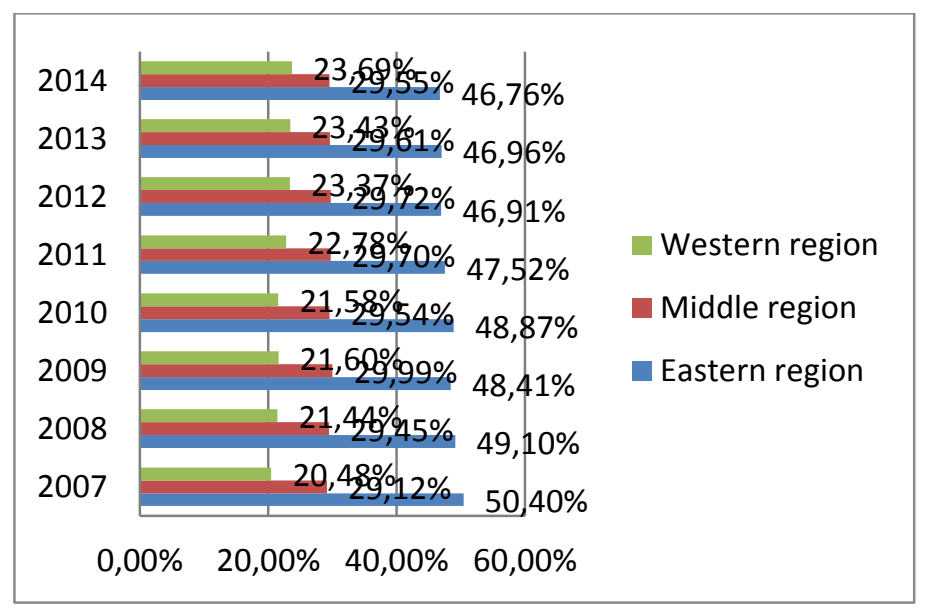

Figure 4 Ratio of Regional Fiscal Spending to Total Fiscal Spending (\%)

(Sources: China National Bureau of Statistics: http://www.stats.gov.cn) 
Figure 5 shows the amount of fiscal support transferred from the East to the West. The change of transfer payment has gone through two cycles. The first cycle happened between 2008 and 2010, in which fiscal spending in the Eastern region decreased by $2.5 \%$, while spending in the Central region increased by $1.14 \%$. Spending in the Western region increased by $4.7 \%$ which was the highest. However, this trend did not last long. In 2010, the government increased the proportion of fiscal spending in the East. The second cycle was the period from 2011 to 2014. In 2011, as shown in Figure 5, the weight of fiscal spending in the east reduced remarkably and the cut was shifted to the West. However, this trend was becoming weak. The change of fiscal spending tended to go up until 2014. In conclusion, the government provides more fiscal spending to the West to facilitate the development but its sustainability is weak.

Figure 5 Growth Rate of Ratios of Regional Fiscal Spending to Total Fiscal Spending (\%)

(Sources: China National Bureau of Statistics: http://www.stats.gov.cn)

In combination of the data of fiscal spending and GDP, it can be found that fiscal policies tend to distribute its spending based on the contribution of GDP per capita. Although there still exists preferential policy for the Western region, this support lacks corresponding strength and sustainability. Whether preferential policy is a significant reason that leads to differences of economic growth among different regions? This paper attempts to answer the above mentioned questions through empirical tests.

\section{Empirical Tests}

\subsection{Theoretical Model}

The econometric model is based on the economic growth theory. This paper regards capital, labor and various fiscal expenditures as independent variables. The economic growth model is of the following form:

$$
\mathrm{Y}=\mathrm{F}(\mathrm{K}, \mathrm{L}, \mathrm{FS}) \text {. }
$$

In order to remove the effect of population, both sides of (1) are divided by $\mathrm{L}$ as shown below:

$$
\mathrm{Y} / \mathrm{L}=\mathrm{F}(\mathrm{K} / \mathrm{L}, \mathrm{FS} / \mathrm{L}) \text {, }
$$

where $\mathrm{Y}$ is GDP, $\mathrm{L}$ is labor force, $\mathrm{Y} / \mathrm{L}$ is GDP per capita, $\mathrm{K} / \mathrm{L}$ is social capital per capita, and FS/L is fiscal expenditures per capita.

\subsection{Data and Variables}

\subsubsection{Data}

This paper selects panel data of 31 provinces of China and divides provinces into 3 different regions, i.e., East, Centre, and West. The Eastern region includes 12 provincial-level administrative divisions: Beijing, Hebei, 
Liaoning, Shanghai, Jiangsu, Zhejiang, Fujian, Shandong, Guangdong, Guangxi and Hainan. The Central region includes 9 provincial-level administrative divisions: Shanxi, Inner Mongolia, Jilin, Heilongjiang, Anhui, Jiangxi, Henan, Hubei and Hunan. The Western region includes 11 provinciallevel administrative divisions: Chongqing, Sichuan, Guizhou, Yunnan, Tibet, Sha'anxi, Gansu, Qinghai, Ningxia and Xinjiang. Some data of fiscal expenditures before 2007 are missing. In order to ensure data consistency among these regions, this paper chooses annual data during 2007-2014 from China National Bureau of Statistics.

\subsubsection{Variables}

This paper uses GDP per capita as dependent variable, and fixed assets per capita and fiscal spending per capita as independent variables, following equation (2). According to data gathered from China National Bureau of Statistics, data of GDP, residential population at year-end and 12 types of fiscal spending after removing some incomplete data such as armed police spending, vehicle purchase tax expenditure and post-earthquake recovery and reconstruction spending are gathered. All data are measured in hundred million.

The 12 types of fiscal spending include general public service, national defense, public safety, education, science and technology, cultural sports and media, social security and employment, medical treatment and public health, environmental protection, urban and rural community affairs, affairs of agriculture, forestry and water resources and transportation. These factors may have effects on regional economic growth. The fiscal spending on education may influence the stock of human resource. The fiscal spending on public safety, environmental protection, science and technology and transportation may act on the attractiveness of enterprises, capital and talents. Fiscal expenditures on general public service and social security and employment play a significant role in life standard and consumption level of people within a region. These types of fiscal spending may affect regional economic development via physical capital, human capital, funds and technology.

Initially a regression equation is proposed as follows:

$\mathrm{y}=\beta_{0}+\beta_{i} X_{i}(i=1,2, \ldots, 13)$.

Table 3 Symbolic Representation of Variables

Variable Symbol Variable Explanation

\begin{tabular}{ll}
\hline $\mathrm{Y}$ & GDP Per Capita \\
$\mathrm{X}_{1}$ & Fiscal Spending on Total Investment in Fixed Assets Per Capita \\
$\mathrm{X}_{2}$ & Fiscal Spending on General Public Service Per Capita \\
$\mathrm{X}_{3}$ & Fiscal Spending on National Defense Per Capita
\end{tabular}




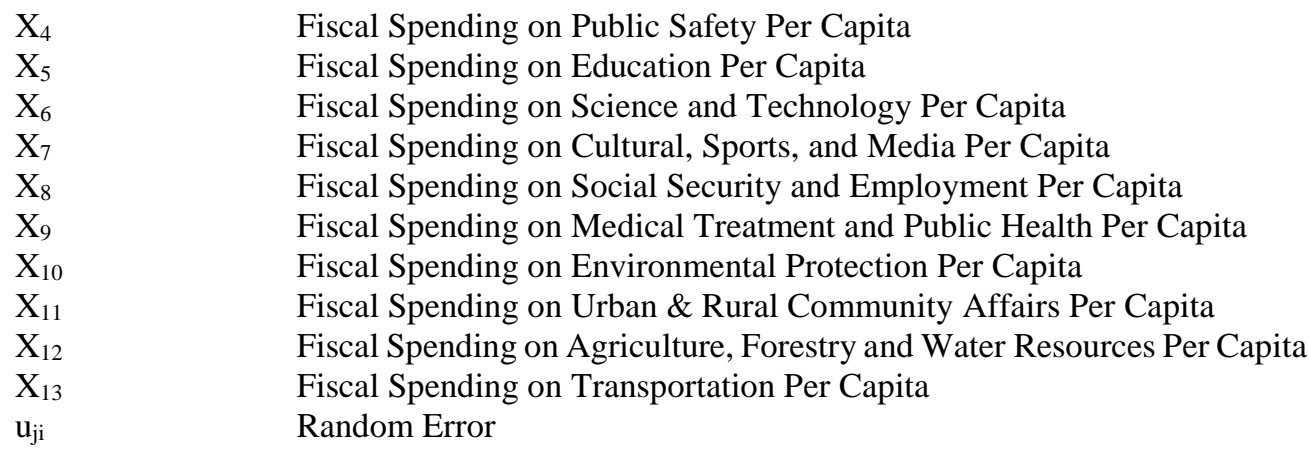

(Sources: China National Bureau of Statistics: http://www.stats.gov.cn)

\subsection{Stationary Test}

In order to avoid spurious regression results, stationary test of variables is conducted first before running any regression in. Test results find that several explanatory variables are non-stationary. This paper takes logarithm and the first order difference by $\frac{\log \left(\mathrm{X}_{\mathrm{t}}\right)-\log \left(\mathrm{X}_{\mathrm{t}-1}\right)}{\log \left(\mathrm{X}_{\mathrm{t}-1}\right)} \approx \frac{\Delta \mathrm{X}_{\mathrm{t}}}{\mathrm{X}_{\mathrm{t}-1}}$. Transformed data become stationary.

\subsection{Empirical Model}

Selection of empirical model is divided into two stages. The first stage is to determine the proper model. Data are respectively introduced to three related models, i.e., constant coefficient model without individual influence, variable-intercept model, and varying-coefficient model. Residual sum of squares of each model are obtained. This paper afterwards calculates $F$ value with related formulations and choose the most appropriate model. The second stage is to decide the influence form of the model. This paper chooses applicable form between fixed effects and random effects. If it already chooses constant coefficient model without individual influence in the first step, then the second step is unnecessary.

In order to study whether the impacts of fiscal financial expenditures of the East and the Centre on economic growth are different from that of the West, this paper introduces interaction terms, i.e., interactions of institution variables among the East and the Centre and various fiscal spending into the model. According to this consideration, the amount of variables exceeds the number of years so this paper selects fixed effect variable interception model as the regression model:

$\mathrm{Y}_{\mathrm{ij}}=\mathrm{m}+\alpha_{\mathrm{i}}^{*}+\beta \sum_{\mathrm{j}=1}^{13} \operatorname{DLog}\left(\mathrm{X}_{\mathrm{ij}}\right)+\sigma \sum_{\mathrm{j}=1}^{13} \mathrm{E}_{\mathrm{i}} \mathrm{DLog}\left(\mathrm{X}_{\mathrm{ij}}\right)+$

$\gamma \sum_{\mathrm{j}=1}^{13} \mathrm{M}_{\mathrm{i}} \mathrm{DLog}\left(\mathrm{X}_{\mathrm{ij}}\right)+\mathrm{u}_{\mathrm{ij}}$,

where $i=1,2,3, \ldots, 31$, which represents Beijing, Hebei, Liaoning, Shanghai, Jiangsu, Zhejiang, Fujian, Shandong, Guangdong, Guangxi, Hainan, Shanxi, 
Inner Mongolia, Jilin, Heilongjiang, Anhui, Jiangxi, Henan, Hubei, Hunan, Chongqing, Sichuan, Guizhou, Yunnan, Tibet, Sha'anxi, Gansu, Qinghai, Ningxia and Xinjiang, respectively. $j=1,2,3 \ldots$, which denotes the time period spanning from 2008 to 2014.

$\mathrm{Ei}=1$, which represent $\mathrm{i}$ provinces of the Eastern region and other regions are represented by $0 . \mathrm{Mi}=1$, which represent i provinces of the Central region and other regions are represented by 0 . In order to increase the degree of model's interpretation and reduce the possibility of omitted variables, this paper builds interaction items $\mathrm{E}_{\mathrm{i}} \mathrm{X}_{\mathrm{ji}}$ and $\mathrm{M}_{\mathrm{i}} \mathrm{X}_{\mathrm{ji}}$ which are the products of the dummy variables and different fiscal spending, respectively. The partial effect of $\mathrm{E}_{\mathrm{i}} \mathrm{X}_{\mathrm{ji}}$ and $\mathrm{M}_{\mathrm{i}} \mathrm{X}_{\mathrm{ji}}$ refer to the coefficients $\sigma$ and $\gamma$ ahead of $\mathrm{E}_{\mathrm{i}} \mathrm{X}_{\mathrm{ji}}$ and $\mathrm{M}_{\mathrm{i}} \mathrm{X}_{\mathrm{ji}}$. The explanatory variables $\mathrm{E}_{\mathrm{i}} \mathrm{X}_{\mathrm{ji}}$ and $\mathrm{M}_{\mathrm{i}} \mathrm{X}_{\mathrm{ji}}$ are $\mathrm{X}_{\mathrm{ji}}, \mathrm{E}_{\mathrm{i}}$ and $\mathrm{M}_{\mathrm{i}}$. The significance of each explanatory variable is tested by related $\mathrm{T}$ values with the significance level of $1 \%, 5 \%$ and $10 \%$.

\subsection{Empirical Results and Interpretation}

\subsubsection{Empirical Results}

Table 4 Empirical Results

\begin{tabular}{|c|c|c|c|c|c|c|}
\hline \multirow[t]{2}{*}{ Variable } & \multicolumn{2}{|c|}{ Regression 1} & \multicolumn{2}{|c|}{ Regression 2} & \multicolumn{2}{|c|}{ Regression 3} \\
\hline & $\begin{array}{l}\text { Regression } \\
\text { Coefficient }\end{array}$ & T-Value & $\begin{array}{l}\text { Regres } \\
\text { Coeffi }\end{array}$ & T-Valu & & $\begin{array}{l}\text { egression } \mathrm{T}-\text { Value } \\
\text { oefficient }\end{array}$ \\
\hline $\operatorname{DLog}\left(\mathrm{X}_{1}\right)$ & $\begin{array}{l}0.491 \\
(0.057)\end{array}$ & $8.55 * * *$ & $\begin{array}{c}0.532 \\
(0.038)\end{array}$ & $14.085 * * *$ & $\begin{array}{c}0.54 \\
(0.036)\end{array}$ & $15.133 * * *$ \\
\hline $\operatorname{DLog}\left(\mathrm{X}_{2}\right)$ & $\begin{array}{l}-0.194 \\
(0.075)\end{array}$ & $-2.576 * * *$ & $\begin{array}{l}-0.166 \\
(0.036)\end{array}$ & $-4.61 * * *$ & $\begin{array}{l}-0.158 \\
(0.033)\end{array}$ & $-4.723 * * *$ \\
\hline $\operatorname{DLog}\left(X_{3}\right)$ & $\begin{array}{l}0.047 \\
(0.024)\end{array}$ & $1.929 *$ & $\begin{array}{l}0.01 \\
(0.015)\end{array}$ & 0.679 & & \\
\hline $\operatorname{DLog}\left(\mathrm{X}_{4}\right)$ & $\begin{array}{l}-0.067 \\
(0.082)\end{array}$ & -0.824 & & & & \\
\hline $\operatorname{DLog}\left(X_{5}\right)$ & $\begin{array}{l}0.185 \\
(0.065)\end{array}$ & $2.834 * * *$ & $\begin{array}{l}0.128 \\
(0.042)\end{array}$ & $3.083 * * *$ & $\begin{array}{l}0.123 \\
(0.041)\end{array}$ & $3.028 * * *$ \\
\hline $\operatorname{DLog}\left(\mathrm{X}_{6}\right)$ & $\begin{array}{l}0.169 \\
(0.055)\end{array}$ & $3.059 * * *$ & $\begin{array}{l}0.14 \\
(0.029)\end{array}$ & $4.822 * * *$ & $\begin{array}{l}0.139 \\
(0.029)\end{array}$ & $4.809 * * *$ \\
\hline $\operatorname{DLog}\left(X_{7}\right)$ & $\begin{array}{l}0.034 \\
(0.06)\end{array}$ & 0.557 & & & & \\
\hline $\operatorname{DLog}\left(X_{8}\right)$ & $\begin{array}{l}0.253 \\
(0.056)\end{array}$ & $4.521 * * *$ & $\begin{array}{c}0.176 \\
(0.023)\end{array}$ & $4.125 * * *$ & $\begin{array}{c}0.169 \\
(0.041)\end{array}$ & $4.094 * * *$ \\
\hline $\operatorname{DLog}\left(X_{9}\right)$ & $\begin{array}{l}0.01 \\
(0.07)\end{array}$ & 0.124 & & & & \\
\hline
\end{tabular}




\begin{tabular}{|c|c|c|c|c|c|c|}
\hline $\operatorname{DLog}\left(\mathrm{X}_{10}\right)$ & $\begin{array}{l}-0.164 \\
(0.045)\end{array}$ & $-3.673 * * *$ & $\begin{array}{l}-0.181 \\
(0.038)\end{array}$ & $-4.823 * * *$ & \multicolumn{2}{|c|}{$\begin{array}{l}-0.174 \\
(0.036)\end{array}$} \\
\hline $\operatorname{DLog}\left(\mathrm{X}_{11}\right)$ & $\begin{array}{l}-0.017 \\
(0.035)\end{array}$ & -0.477 & & & & \\
\hline $\operatorname{DLog}\left(\mathrm{X}_{12}\right)$ & $\begin{array}{l}-0.055 \\
(0.091)\end{array}$ & -0.601 & & & & \\
\hline $\operatorname{DLog}\left(\mathrm{X}_{13}\right)$ & $\begin{array}{l}-0.032 \\
(0.025)\end{array}$ & -1.275 & & & & \\
\hline $\operatorname{EDLog}\left(\mathrm{X}_{1}\right)$ & $\begin{array}{l}-0.29 \\
(0.082)\end{array}$ & $-3.554 * * *$ & $\begin{array}{r}-0.289 \\
(0.058)\end{array}$ & $-4.967 * * *$ & $\begin{array}{l}-0.3 \\
(0.056\end{array}$ & $\begin{array}{l}-5.362 * * * \\
6)\end{array}$ \\
\hline $\operatorname{EDLog}\left(\mathrm{X}_{2}\right)$ & $\begin{array}{c}0.542 \\
(0.137)\end{array}$ & $3.944 * * *$ & $\begin{array}{c}0.522 \\
(0.095)\end{array}$ & $5.466^{* * * *}$ & $\begin{array}{c}0.514 \\
(0.094)\end{array}$ & $5.451 * * *$ \\
\hline $\operatorname{EDLog}\left(\mathrm{X}_{3}\right)$ & $\begin{array}{l}-0.047 \\
(0.034)\end{array}$ & -1.376 & & & & \\
\hline $\operatorname{EDLog}\left(\mathrm{X}_{4}\right)$ & $\begin{array}{c}0.226 \\
(0.138)\end{array}$ & 1.636 & & & & \\
\hline $\operatorname{EDLog}\left(\mathrm{X}_{5}\right)$ & $\begin{array}{l}-0.096 \\
(0.111)\end{array}$ & -0.862 & & & & \\
\hline $\operatorname{EDLog}\left(\mathrm{X}_{6}\right)$ & $\begin{array}{l}-0.099 \\
(0.082)\end{array}$ & -1.201 & & & & \\
\hline $\operatorname{EDLog}\left(\mathrm{X}_{7}\right)$ & $\begin{array}{l}-0.171 \\
(0.08)\end{array}$ & $-2.133 * *$ & $\begin{array}{l}-0.131 \\
(0.047)\end{array}$ & $-2.812 * * *$ & $\begin{array}{l}0.132 \\
(0.046)\end{array}$ & $-2.84 * * *$ \\
\hline $\operatorname{EDLog}\left(\mathrm{X}_{8}\right)$ & $\begin{array}{l}-0.265 \\
(0.081)\end{array}$ & $-3.269 * * *$ & $\begin{array}{l}-0.158 \\
(0.064)\end{array}$ & $-2.474 * *$ & $\begin{array}{l}-0.146 \\
(0.061)\end{array}$ & $-2.391 * *$ \\
\hline $\operatorname{EDLog}\left(\mathrm{X}_{9}\right)$ & $\begin{array}{c}0.283 \\
(0.105)\end{array}$ & $2.691 * * *$ & $\begin{array}{l}0.318 \\
(0.052)\end{array}$ & $6.143 * * *$ & $\begin{array}{c}0.32 \\
(0.051)\end{array}$ & $6.227 * * *$ \\
\hline $\operatorname{EDLog}\left(\mathrm{X}_{10}\right)$ & $\begin{array}{r}0.236 \\
(0.054)\end{array}$ & $4.402 * * *$ & $\begin{array}{l}0.24 \\
(0.047)\end{array}$ & $5.14 * * *$ & $\begin{array}{l}0.232 \\
(0.045)\end{array}$ & $5.17 * * *$ \\
\hline $\operatorname{EDLog}\left(\mathrm{X}_{11}\right)$ & $\begin{array}{c}0.074 \\
(0.06)\end{array}$ & 1.238 & & & & \\
\hline $\operatorname{EDLog}\left(\mathrm{X}_{12}\right)$ & $\begin{array}{l}-0.186 \\
(0.109)\end{array}$ & $-1.71 *$ & $\begin{array}{l}-0.274 \\
(0.049)\end{array}$ & $-5.635 * * *$ & $\begin{array}{l}-0.265 \\
(0.046)\end{array}$ & $-5.706 * * *$ \\
\hline $\operatorname{EDLog}\left(\mathrm{X}_{13}\right)$ & $\begin{array}{r}0.032 \\
(0.033)\end{array}$ & 0.985 & & & & \\
\hline $\operatorname{MDLog}\left(\mathrm{X}_{1}\right)$ & $\begin{array}{r}-0.639 \\
(0.101)\end{array}$ & $-6.297 * * *$ & $\begin{array}{c}0.65 \\
(0.076)\end{array}$ & $-8.511 * * *$ & $\begin{array}{l}-0.658 \\
(0.074)\end{array}$ & $-8.846 * * *$ \\
\hline $\operatorname{MDLog}\left(\mathrm{X}_{2}\right)$ & $\begin{array}{c}0.152 \\
(0.116)\end{array}$ & 1.317 & & & & \\
\hline $\operatorname{MDLog}\left(\mathrm{X}_{3}\right)$ & $\begin{array}{c}-0.09 \\
(0.049)\end{array}$ & $-1.824 *$ & $\begin{array}{c}-0.01 \\
(0.041)\end{array}$ & -0.247 & & \\
\hline $\operatorname{MDLog}\left(\mathrm{X}_{4}\right)$ & $\begin{array}{l}0.484 \\
(0.181)\end{array}$ & $2.672 * * *$ & $\begin{array}{c}0.338 \\
(0.111)\end{array}$ & $3.041 * * *$ & $\begin{array}{c}0.34 \\
(0.091)\end{array}$ & $3.73 * * *$ \\
\hline $\operatorname{MDLog}\left(X_{5}\right)$ & $\begin{array}{l}-0.032 \\
(0.102)\end{array}$ & -0.308 & & & & \\
\hline
\end{tabular}




\begin{tabular}{|c|c|c|c|c|c|}
\hline $\operatorname{MDLog}\left(\mathrm{X}_{6}\right)$ & $\begin{array}{l}-0.134 \\
(0.069)\end{array}$ & $-1.941 *$ & $\begin{array}{l}-0.121 \\
(0.047)\end{array}$ & $-2.559 * *$ & $\begin{array}{l}-0.118-2.544 * * \\
(0.046)\end{array}$ \\
\hline $\operatorname{MDLog}\left(\mathrm{X}_{7}\right)$ & $\begin{array}{l}0.076 \\
(0.119)\end{array}$ & 0.635 & & & \\
\hline $\operatorname{MDLog}\left(\mathrm{X}_{8}\right)$ & $\begin{array}{l}-0.25 \\
(0.129)\end{array}$ & $-1.933 *$ & $\begin{array}{l}-0.166 \\
(0.092)\end{array}$ & $-1.807 *$ & $\begin{array}{l}-0.16-1.761 * \\
(0.091)\end{array}$ \\
\hline $\operatorname{MDLog}\left(\mathrm{X}_{9}\right)$ & $\begin{array}{r}-0.065 \\
(0.12)\end{array}$ & -0.537 & & & \\
\hline $\operatorname{MDLog}\left(\mathrm{X}_{10}\right)$ & $\begin{array}{l}0.267 \\
(0.068)\end{array}$ & $3.925^{* * *}$ & $\begin{array}{l}0.311 \\
(0.061)\end{array}$ & $5.12 * * *$ & $\begin{array}{l}0.3045 .132 * * * \\
(0.059)\end{array}$ \\
\hline $\operatorname{MDLog}\left(X_{11}\right)$ & $\begin{array}{l}0.264 \\
(0.067)\end{array}$ & $3.915 * * *$ & $\begin{array}{l}0.308 \\
(0.051)\end{array}$ & $6.024 * * *$ & $\begin{array}{l}0.307 \quad 6.506^{* * *} \\
(0.047)\end{array}$ \\
\hline $\operatorname{MDLog}\left(\mathrm{X}_{12}\right)$ & $\begin{array}{l}0.0158 \\
(0.125)\end{array}$ & 0.126 & & & \\
\hline $\operatorname{MDLog}\left(\mathrm{X}_{13}\right)$ & $\begin{array}{l}0.059 \\
(0.046)\end{array}$ & 1.29 & & & \\
\hline 0.00 & & $\begin{array}{c}0.346 \\
(0.002)\end{array}$ & $\begin{array}{l}0.0005 \\
(0.002)\end{array}$ & 0.295 & $\begin{array}{ll}0.0005 & 0.294 \\
(0.002) & \end{array}$ \\
\hline $\mathrm{R}^{2}$ & & 0.985 & 0.983 & & 0.983 \\
\hline Adjust $\mathrm{R}^{2}$ & & 0.978 & 0.978 & & 0.978 \\
\hline
\end{tabular}

Note: (a) All results are kept three places of decimal. If 3 digits after the decimal point of the number are equal to 0 , then this number contains up to 4 digits after the decimal point. Furthermore, if the third digit after the decimal point of the number is equal to 0 , this number contains up to 2 digits after the decimal point.

(b) *,**, and *** represent $10 \%, 5 \%$, and $1 \%$ level of significance, respectively.

(c) Regression 1 - Regression 3 all use data from 31 provinces of China. Regression 2 removes insignificant variables $\operatorname{DLog}\left(\mathrm{X}_{4}\right), \mathrm{DLog}\left(\mathrm{X}_{7}\right), \mathrm{DLog}\left(\mathrm{X}_{9}\right), \mathrm{DLog}\left(\mathrm{X}_{11}\right), \operatorname{DLog}\left(\mathrm{X}_{12}\right), \operatorname{DLog}\left(\mathrm{X}_{13}\right)$, $\operatorname{EDLog}\left(\mathrm{X}_{3}\right), \mathrm{EDLog}\left(\mathrm{X}_{4}\right), \mathrm{EDLog}\left(\mathrm{X}_{5}\right), \mathrm{EDLog}\left(\mathrm{X}_{6}\right), \mathrm{EDLog}\left(\mathrm{X}_{11}\right), \mathrm{EDLog}\left(\mathrm{X}_{13}\right), \operatorname{MDLog}\left(\mathrm{X}_{2}\right)$, $\operatorname{MDLog}\left(\mathrm{X}_{5}\right), \operatorname{MDLog}\left(\mathrm{X}_{7}\right), \operatorname{MDLog}\left(\mathrm{X}_{9}\right), \operatorname{MDLog}\left(\mathrm{X}_{12}\right)$ and $\operatorname{MDLog}\left(\mathrm{X}_{13}\right)$ from Regression 1. Regression 3 removes insignificant variables $\operatorname{DLog}\left(\mathrm{X}_{3}\right)$ and $\operatorname{MDLog}\left(\mathrm{X}_{3}\right)$ from Regression 2. (d) Bracket denotes standard deviation.

This paper estimates empirical model by using the method of ordinary least squares (OLS) and judge the significance of different variables based on the significant levels of $1 \%, 5 \%$ and $10 \%$ with $\mathrm{T}$ values. At first, this paper uses total social fixed asset investment per capita, 12 fiscal expenditures per capita and related interaction items to run regression. Then it runs more regressions by deleting insignificant variables. This paper presents 3 regression tests and chooses the third regression result as the final empirical model shown as below:

$$
\begin{aligned}
\mathrm{Y}= & -0.0005+\alpha_{i}^{*}+0.54 \mathrm{DLog}\left(\mathrm{X}_{1}\right)- \\
& 0.158 \mathrm{DLog}\left(\mathrm{X}_{2}\right)+0.123 \mathrm{DLog}\left(\mathrm{X}_{5}\right)+0.139 \mathrm{DLog}\left(\mathrm{X}_{6}\right)+0.169 \mathrm{DLog}\left(\mathrm{X}_{8}\right)- \\
& 0.174 \mathrm{DLog}\left(\mathrm{X}_{10}\right)-0.3 \mathrm{EDLog}\left(\mathrm{X}_{1}\right)_{+} 0.514 \mathrm{EDLog}\left(\mathrm{X}_{2}\right)-0.132 \mathrm{EDLog}\left(\mathrm{X}_{7}\right)-
\end{aligned}
$$


0.146EDLog $\left(\mathrm{X}_{8}\right)_{+} 0.32 \mathrm{EDLog}\left(\mathrm{X}_{9}\right)+0.232 \mathrm{EDLog}\left(\mathrm{X}_{10}\right)-0.265 \mathrm{EDLog}\left(\mathrm{X}_{12}\right)-$

0.658MDLog $\left(\mathrm{X}_{1}\right)+0.34 \mathrm{MDLog}\left(\mathrm{X}_{4}\right)-0.118 \mathrm{MDLog}\left(\mathrm{X}_{6}\right)-$

0.16MDLog $\left(\mathrm{X}_{8}\right)+0.304 \mathrm{MDLog}\left(\mathrm{X}_{10}\right)+0.307 \mathrm{MD} \log \left(\mathrm{X}_{11}\right)$

\subsubsection{Empirical Analysis}

Table 5 Regional Analysis

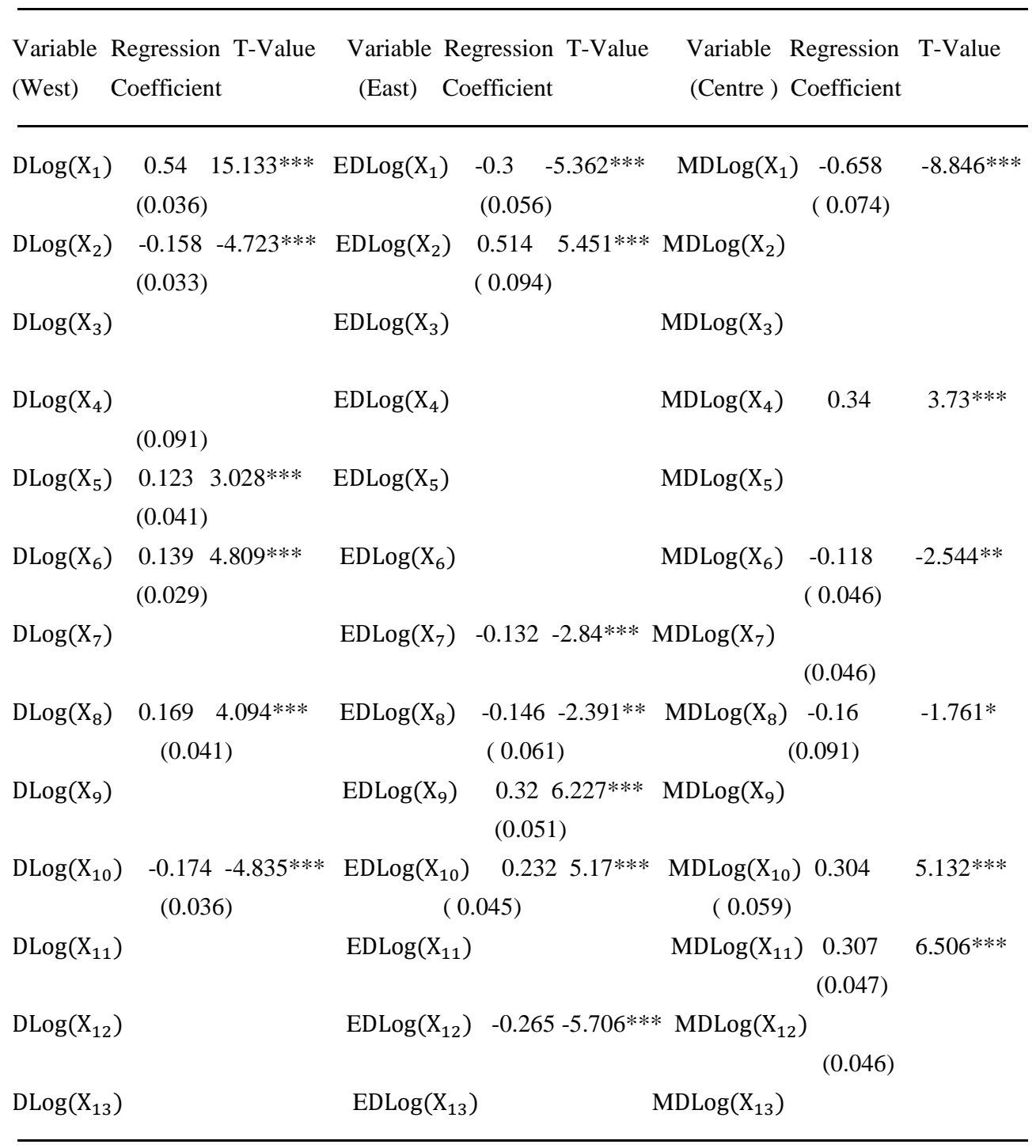

Note: (a) *,**, and $* * *$ represent $10 \%, 5 \%$, and $1 \%$ levels of significance, respectively.

(b) Bracket denotes standard deviation.

Overall, the impact of total investment in fixed assets per capita on GDP per capita is significant. A $1 \%$ increase in investment of fixed assets per capita 
is associated with a $0.54 \%$ increase in GDP per capita. However, a $1 \%$ increase in investment of fixed assets per capita would increase $0.24 \%$ of GDP per capita in the East which is $0.3 \%$ less than that of the West. This phenomenon may result from over-capitalization in the East during the period of economic structural adjustment. By contrast, a 1\% increase in investment of fixed assets per capita would reduce $0.118 \%$ of GDP per capita in the Centre which is $0.658 \%$ less than that of the West. In other words, economic structure development in the Centre has lagged behind. To sum up, excess capacity of the East and the Centre should be somehow shifted to the West.

According to 12 types of fiscal spending, there are 10 types that could have impacts on GDP per capita and 5 types could influence the economic growth of three regions. This paper sets the Western region as the reference group. Fiscal expenditures on education, science and technology and social security and employment have a positive effect on GDP per capita. The relation between public financial spending on education and GDP per capita is positive without regional disparity. A $1 \%$ increase in the spending of education per capita will increase $0.123 \%$ of GDP per capita. As for the fiscal spending on science and technology, a $1 \%$ increase in this spending will increase $0.139 \%$ of GDP per capita in the West and the East. It increases $0.021 \%$ of GDP per capita in the Centre which is $0.118 \%$ less than that of the West and that of the East. This means the efficiency of technical investment in the Centre is lower than that of the West and the East. The third spending is about social security and employment. A 1\% increase in the spending of social security and employment will increase $0.169 \%, 0.023 \%$ and $0.009 \%$ of GDP per capita in the West, the East and the Centre, respectively. Spending on social security and employment in the West refers to the productive investment given as a form of subsidy given to impoverished people with labor capacity to strengthen their working capacity and further promote economic development. However, this spending in the East and the Centre is more used to help poor people who lack labor capacity so that this expenditure plays a consumptive role in the GDP per capita within this area.

General public service mainly means 37 various tasks of the National People's Congress, the Chinese People's Political Consultative Conference, development and reforms etc.. Therefore, the spending on general public service is primarily used as operational expenditures of government attributed to the consumptive fiscal spending. In the West and the Centre, a 1\% increase in the spending of general public service decreases $0.158 \%$ of GDP per capita, which indicates that the consumption of spending on general public service is higher in these regions. By contrast, a $1 \%$ increase in the spending of general public service increases $0.514 \%$ of GDP per capita. This result reveals that the government in the East plays a boosting role in regional economic development. Environmental protection generally is characterized as long 
cycle, so current spending on this aspect is attributed to consumption to GDP per capita. A $1 \%$ increase in the spending on environmental protection is associated with a $0.174 \%$ decrease in GDP per capita in the West. In contrast, the economic development in the East and the Centre has already reached to a higher level so that the spending on environmental protection could facilitate GDP per capita at present. A $1 \%$ increase in the spending of environmental protection could increase $0.058 \%$ of GDP per capita which is $0.232 \%$ higher than that of the West. The efficiency of the spending on environmental protection is higher in the Centre. A $1 \%$ increase in the spending of environmental protection could promote $0.13 \%$ of GDP per capita which is $0.304 \%$ higher than that of the West. Therefore, the East has already passed the easiest part of economic growth while the West is still in the process.

Fiscal expenditures on cultural sports and media, medical treatment and public health and agriculture, forestry and water resources only have effects on the economic growth of the East, and insignificant effect on that of the Centre and the West. A $1 \%$ increase in the spending of medical treatment and public health is linked to a $0.32 \%$ increase of GDP per capita. There may exist two main reasons for this result. On the one hand, population density of the East is more intensive than that of the Center and the West with higher investment on medical treatment which could boost the GDP per capita of the East. On the other hand, compared to the Centre and the West, the East has more medical resource and higher medical standards and efficiency so that hospitals in this region could address more difficult miscellaneous diseases with higher demands. As a result, the spending on medical treatment and public health has a greater impact on its GDP per capita. A $1 \%$ increase in the spending on cultural sports and media will decrease $0.132 \%$ of GDP per capita, while the impacts on the Centre and the West are insignificant. This result not only indicates that cultural industry develops faster in the East than other regions, but also shows that investments on culture and media belong to consumptive expenditures. Furthermore, a $1 \%$ increase in the spending on agriculture, forestry and water resources would bring a $0.265 \%$ decrease of GDP per capita. The reason is that the industry pattern in this area has reached a high level with lower proportion of primary industry, which is more beneficial to reduce the positive impacts of primary industry on GDP per capita.

There are only two types of fiscal spending, i.e., public safety and urban and rural community affairs that promote the GDP per capita of the Centre. A $1 \%$ increase in the spending of public safety will increase $0.34 \%$ of GDP per capita, which shows that public security situation in the Centre may lie in a lower condition so that there is a significantly positive relation between spending on public safety and economic development. A $1 \%$ increase in spending on urban and rural community affairs is associated with a $0.307 \%$ 
increase in GDP per capita. This result indicates that due to backward economic development of the Centre, there still exist various issues about urban and rural so that the increase of the spending on urban and rural community affairs could remarkably accelerate regional economic development.

Among 12 types of fiscal expenditures, spending on national defense and transportation has a neutral effect on GDP per capita, which shows that the idea of "intend to amass a fortune, then repair road first" does not implement effectively. There are developed road and rail networks. However, there is insignificant relation between fiscal spending on transportation and economic growth.

According to above analysis, the economic development among the East, the Centre and the West are not in the same level so that public financial expenditures have different functions on GDP per capita in different regions.

Most of fiscal financial expenditures do not significantly affect GDP per capita of the West. Fiscal expenditures on education, science and technology and social security and employment mainly boost GDP per capita of the West, which shows that "West Development" is a policy used to directly stimulate economic development with the investments of soft power such as education and technology rather than the construction of highway. The increase in fiscal expenditures on general public service and environmental protection will result in the reduction of GDP per capita. The reason is that the West is a vast territory with a sparse population and low government administrative efficiency. Furthermore, environmental protection is a heavy task for the West which becomes effective in long run. Therefore, spending on this aspect may hamper GDP per capita in short term.

As for the East, it has higher economic development level so it have special demands of fiscal financial expenditures. First of all, the industrial structure of the East is in the leading position because of its high economic development level. The overall demands of medical treatment and environmental protection that could be beneficial to the quality of economic development and the living standard of people are larger than that of other regions. Secondly, government in this region plays an effective role in the economic growth with high functions of resource integration and low consumption of general public service. Finally, there are increasing demands of spending on medical treatment and environmental protection that could increase the labor efficiency via the improvement of labor's health. As for the objectives of economic development, fiscal expenditures on cultural sports and media and social security and employment play a negative effect on GDP per capita. With the decrease of the proportion of primary industry, fiscal spending on agriculture, forestry and water resources plays a declining positive role on economic growth. 
The Centre has 5 special factors that influence its economic development. Fiscal expenditures on public safety, environmental protection and urban and rural community affairs could boost the economic development of the Centre. Compared to the East, the Centre has more towns and villages but less big cities or developed cities. Fiscal spending on urban and rural affairs plays a significant role in regional economic growth with the limitation of market economy on disposal of urban and rural affairs. Furthermore, due to the poor public security environment of the Centre, there is a positive relation between fiscal spending on this aspect and economic development. Besides, fiscal expenditure on environmental protection also has an essential effect on GDP per capita because of serious industrial pollution in this area. However, public spending on science and technology does not stimulate economic growth as expected. Empirical results indicate that investment in this aspect seems overspend with low efficiency of government. Fiscal spending on general public service would hamper GDP per capita which means that government does not play a positive role in regional economic development.

\section{Conclusions and Policy Implications}

Based on empirical results, this paper proposes the following policy implications.

1. Fiscal expenditures of government could provide some public goods which is hard to be supplied by the market-oriented economy, which could have an essential effect on the economic development.

2. The development levels of economy among the East, the Centre and the West of China are very different from each other. Therefore, investments of different types of fiscal spending in different regions have to be accord with development laws of local economy.

3. In addition to spending on education and technology, the East has advanced industrial structure, high living standard and its economy depends heavily on fiscal expenditures of medical treatment and environmental protection. Therefore, the increase of fiscal expenditures is needed to improve government performance and efficiency of public resources. However, there is overinvestment in the cultural sports and media and agriculture, forestry and water resources.

4. The development level of the Centre lies in the medium. City and countryside play a significant role in regional development. Therefore, it is necessary to increase the fiscal expenditures on urban and rural community affairs and public safety to accelerate the development of the Centre. However, there is a negative relation between spending on science and technology and GDP per capita, which indicates that spending on this aspect is too much.

5. It is more significant to increase factors that could promote the economic growth of the West such as education and science and technology. However, 
this paper does not find any sound evidences to prove that expenditures on transportation and environmental protection are more significant to the development of the West as expected.

\section{References:}

Barro, R.J., Government Spending in a Simple Model of Endogenous Growth[A], Journal of Political Economy , 1990, 98(5), p103-125

Barro, R.J and Sala-i-Martin,X., Public Finance in Models of Economic Growth[A], Review of Economic Studies, 1992, 59, p645-61

Lucas, R.E. Jr., On the Mechanics of Economic Development[J], Journal of Monetary Economics, 1988, 22, p3-42

Devarajan, S., Swaroop, V, and Zou, H.F, The Composition of Public Expenditures and Economic Growth[J], Journal of Monetary Economics 37(2), 1996, p313-344

Knoop, T.A., Growth Welfare and the Size of Government[J], Journal of Economic Inquiry, 1999, p103-109

Arrow, K.J. and Kurz, M., Public Investment, the Rate of Return, and Optimal Fiscal Policy, Resources for the Future Inc, Johns Hopkins Press: Baltimore and London, 1970, p1-205

Aschauer, D.A., The Equilibrium Approach to Fiscal Policy[A], Journal of Money, Credit, and Banking 20, 1988, p41-62

Butkiewicz, J.L. and Yanikkaya, H, Institutions and the impact of government spending on growth[A], Journal of Applied Economics, 2011, 2, p319-341

Boldeanu, F.T, Ion, M.S, The influence of public and private sector investment on economic growth in the European union[A], Doctoral Studies of Lucian Blaga University, 2015, p1-11

Adrienn, E., The Analysis of Long Run Growth Oriented Fiscal Policy[A], Economic Analysis, 2010, 1-2, p25-33

Liu,Junying, A Cointegration Analysis on Public Expenditure Transaction and Economic Development[A], Economic Problems, 2009, p18-22

$\mathrm{Ju}$ Fan, Public products supply, capital accumulation and economic aggregation, World Economic Outlook, 2009, p30-34

Li Zhen, Liu Xiaoyong, Spillover, Public Products and Economic Growth: The Empirical Analysis and Effect Decomposition Based on Spatial Panel Model[A], Statistics \& Information Forum, 2012, p57-63

Tang Ying, Zhao Wenjun, Public Expenditure and Transformation of Economic Growth Pattern of China: An Empirical Analysis Based on Panel Data Of China's Provinces[A], Finance \& Trade Economics, 2014, p14-29 